
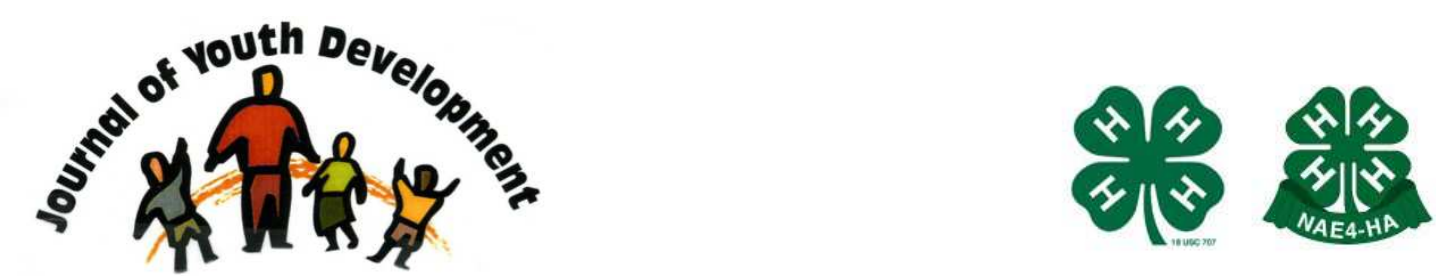

Bridging Research \& Practice

\title{
Applying Marketing Concepts to Non-Profit/Educational Organizations: The Youth Professional's Responsibilities in Program Marketing \& Promotion
}

Keith G. Diem

Oregon State University Extension Service

Corvallis, OR

keith.diem@oregonstate.edu 


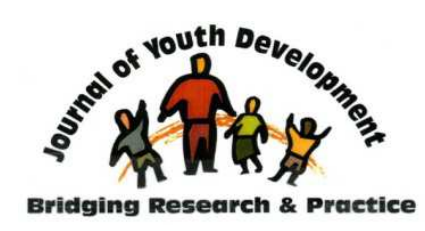

\section{JOURNAL OF YOUTH DEVELOPMENT \\ bridging research and practice

\section{Applying Marketing Concepts to \\ Non-Profit/Educational Organizations: \\ The Youth Professional's Responsibilities \\ in Program Marketing \& Promotion}

Keith G. Diem
Oregon State University
Abstract: The degree of participation in community-based youth
development programs is typically affected by both the recruitment and
retention of participants. A review of literature over more than forty
years revealed the value of marketing and promotion to the viability of a
company, product, or organization and how it may contribute to
company sales or an organization's membership. This article is focused
on the application of marketing concepts to a non-profit organization or
educational program. Using a marketing approach to program
development can result in improved program quality as well as
increased enrollment. Utilizing marketing activities such as needs
assessment will aide in ensuring the program remains current in
meeting needs and interests of clientele, the community, and society.
Promoting an accurate and relevant image is a key in making sure
people realize the value of your program.

\section{Theoretical Background}

The degree of participation in community-based youth development programs is typically affected by both the recruitment and retention of participants. A review of literature over more than forty years revealed the value of marketing and promotion to the viability of a company, product, or organization and how it may contribute to company sales or an organization's membership. This article is focused on the application of marketing concepts to a non-profit organization or educational program. 
Marketing has too often been equated with selling, promotion, advertising, public relations, and publicity. Although these terms are related, they are not identical. The distinction between marketing and selling is especially important to note. The sales concept is "a management orientation that assumes that consumers will either not buy or not buy enough of the organization's 'products' unless the organization makes a substantial effort to stimulate their interest in its 'products'." In contrast, the marketing concept is "a management orientation that holds that the key to achieving organizational goals consists of the organization's determining the needs and wants of target markets and adapting itself to delivering the desired satisfactions more effectively and efficiently than its competitors" (Kotler, 1980).

Marketing aims to meet customer/clientele needs and keep them satisfied, and thus would encourage customer loyalty to a product, or in this case, participant/member retention. However, the application of variables involved in a market mix (product, price, promotion, and place) should also influence new participants in their decisions to join an organization. If the market mix is right for them, they should be willing to enroll (Pride \& Ferrell, 1985).

"Promotion . . . is the communication function of marketing" (Engel, Warshaw, \& Kinnear, 1983, p. 16). It "refers to communication undertaken to persuade others to accept ideas, concepts, or things." Pride and Ferrell (1985, p. 331) stated that "Several types of promotional methods can be used to communicate with individuals, groups, and organizations" and that "When an organization combines specific ingredients to promote a particular product, that combination constitutes a promotion mix for that product." They listed four major categories of promotion that can be included in an organization's promotion mix: advertising, personal selling, publicity, and sales promotion. Within each category are a multitude of specific individual promotional methods available, from traditional mass media to emerging technologies such as web-based marketing, blogs, etc.

The desired outcome of promotional activity is based on the hierarchy of effects hypothesis, where promotion works "to stimulate awareness, which leads to attitude change, which leads to behavioral change." Thus, it "is basically a model of consumer response to promotional activity ... . [where] the consumer passes through the stages of awareness, knowledge (cognitive), liking and preference (affective), intention-to-buy or conviction, and purchase (behavioral)" (Engel, Warshaw, \& Kinnear, 1983, p. 164). This is supported by models developed by Engel and Blackwell (1982) and Fishbein and Ajzen (1975).

One aim of promotion is to communicate a favorable image of an organization (Pride \& Ferrell, 1985). Consequently, since Boyle and Brown (1964, p. 34) stated that "The image that people have of an organization will determine, to a great extent, their participation [in it]," then this would involve not only an initial decision to join an organization, but also a decision to remain in it, thus relating promotion to the aspect of retention as well as recruitment. Meenaghan (1995) stated "In an increasingly competitive marketplace, greater emphasis is being placed on brand image development as the basis for consumer discrimination. Advertising has a central role to play in developing brand image, whether at the corporate, retail or product level. It informs consumers of the functional capabilities of the brand while simultaneously imbuing the brand with symbolic values and meanings relevant to the consumer."

Even after years of research and practice to determine the most effective promotional methods, there appear to be no clear answers regarding this complex topic. Engel, Warshaw, and 
Kinnear (1983, p. 379) described a factorial experimental design employed by Ford Motor Company to compare sales in regions using various combinations of media in an advertising campaign. Ford reported that the data "revealed a definite relationship between advertising and sales but no significant advantage for any of the media tested." A variety of other studies (Johnston, 1982; Lawson, \& Dail, 1966; Marsh, \& Knox, 1966; Scherer, 1980; Wilson, 1963) have reported mixed results of the success of specific promotional methods and/or their potential for reaching audiences, depending on the objectives, use, and location of use of such methods. A study related to $4-\mathrm{H}$ youth programming (Williams, 2004, p. 81) "indicated that race/ethnicity is a factor for respondents when choosing [media]" and therefore, "marketing strategies should be prioritized and focused where information can be disseminated to specific clientele through avenues that are being used by them."

Salcedo (1974) reported that a variety of channels have been shown to be more useful than public service mass media alone. Therefore, mass media, especially heavy reliance on a single type do not appear to be the answer to all problems of image and recruitment, emphasizing the need for the use of a variety of promotion methods. Literature related to learning theory and instructional media has also supported the value of using a variety of communication channels.

In a study related to promotion of the 4-H Youth Development Program, Diem (1987) found "that the mere frequency of use of promotional methods will not be effective in attaining goals of promotion. The quality of promotion efforts is more likely to be a factor. Therefore, promotion must communicate an accurate, up-to-date, and appropriate image of the [program]." The study recommended that if [program leaders] "are trying to highlight innovative, modern programs to new audiences, then they must do just that. Focus on the features of the program that will interest the audience you are trying to reach. Furthermore, use media your audiences are accustomed to, and consider the education level of that group."

"Social marketing has taken ideas from commercial marketing and used them to address social and health problems. The marketing concept of consumer orientation and tolls such as the marketing mix have been successfully applied to health and social behaviors ... Social marketers have targeted the citizen to bring about individual change, as well as policy makers and stakeholders to bring about institutional and social change" (Hastings, 2003, p. 6).

Indeed, although the term marketing has been heard frequently in recent years, it still does not seem to be clearly understood by many people in social service settings. While marketing has been a fundamental activity in the business environment, some aspects of the concept are applicable to non-business settings as well. Besides being a distinctly different management philosophy and orientation of an organization, marketing consists of activities performed by the management of the organization. One of the marketing activities performed by a program leader is the formulation of a marketing mix. A marketing mix consists of four decision variables, often known as the 4 P's: Product, Promotion, Price, and Place. Another marketing activity performed by a program leader is the development of a marketing strategy. A marketing strategy encompasses selecting and analyzing a target market (the group of people whom the [organization] wants to reach) and creating and maintaining an appropriate marketing mix (product, price, promotion, distribution) that will satisfy those people (Pride, \& Ferrell, 1985, p. 25).

George, Buchanan, and Bramblett (1976) claimed that a marketing management orientation 
supplements the work of adult educators such as Houle and Knowles, who were instrumental in using program planning models to develop programs for clients, and is easier to understand by youth development professionals. The authors proclaimed that the marketing approach "reorients the perspective of the [program leader so that] instead of focusing on a set of available institutional services, the [program leader] now begins the program development process based on felt and ascribed client needs" (p. 17). They described the following University of Georgia case as evidence of the potential results of applying marketing concepts to an educational organization:

In applying these marketing techniques, the service activities of the university have increased. The average annual increase in the number of programs held on campus has been $20 \%$ for the last 3 years, while the number of off-campus programs and projects conducted in the same period has tripled. This expansion has occurred without additions to the resource base. In addition, the pre- and post-program evaluations have revealed that the quality of service now being received by the clientele groups has risen sharply (p. 16).

George, et al. concluded by stating that the "program will ultimately fail unless marketing information is collected and used to develop marketing plans that effectively serve the ... unit's publics" (p. 19).

Needs assessment is a valuable marketing function. For example, a nationwide needs assessment was conducted (Diem, 2007) to ensure that plans to expand the Clemson University Youth Development Leadership (YDL) degree program would meet the needs of organizations related to the youth development profession. In the process of conducting it, a variety of findings proved beneficial for determining similarities and differences among youth development organizations as well as implications for the types of degrees that would be most valuable for professionals in contemporary youth development organizations.

Whitlock and Hamilton (2003) provided perspective on multiple approaches to the role of youth surveys in understanding youth needs and improving communities as contexts for youth development. National Longitudinal Surveys of Youth (2002) conducted by the U.S. Department of Labor Bureau of Labor Statistics have served as an important tool for economists, sociologists, and other researchers. Other surveys (Diem, 1990; Diem, 1991; Diem, 1992b/c; Diem, 1994; Diem, \& Rothenburger, 2001; Warner, Christenson, Dillman, \& Salant, 1996) have looked at the needs, interests, and perceptions of youth, adult volunteers, and the public regarding educational events and programs.

In recent years, an important application of marketing concepts has been to demonstrate and communicate program impact to stakeholders. Impact ... is the positive difference we make in people's lives as a result of programs we conduct. These programs may include teaching, published curriculum, volunteer training, or applied research and, may or may not involve the public directly while they are being delivered. Yet the results programs achieve must ultimately change people's attitudes or behavior, or benefit society in other ways (Diem, 1997). "Proving program impact is important to:

- justify the investment of time and effort, as well as the dedication of public and private funds. 
- earn and build professional, organizational, and political credibility and support.

- satisfy the requirements of political bodies and funding agencies.

- yield tangible results that serve as a basis for scholarly publications, as well as awards and recognition.

- determine, to what degree, that participants achieve intended results" (Diem, 2003).

\section{Putting Marketing Concepts into Practice}

Developing a Marketing Mix with the Four Decision Variables (the 4 P's): In creating a marketing strategy, a marketing mix is created for each group of people the organization aims to reach. Such a "target market" is "a group of persons for whom an organization creates and maintains a marketing mix that specifically fits the needs and preferences of that group. The organization must determine if it has the resources to produce a marketing mix that meets the needs of a particular target market and whether satisfying those needs is consistent with the organization's overall objective. It must also determine what competitors are already serving the given target market" (Pride, \& Ferrell, 1985).

Here are some key considerations for developing an appropriate marketing mix:

1. Product

This can be a good, service, or idea. Determine what the organization has to offer compared to other agencies and organizations. What makes it unique, relevant, and perceived as valuable?

2. Price

How much does the "product" cost? Consider both actual costs (such as fees charged) and opportunity costs (such as the time dedicated to participate in an inexpensive workday program may require paying for child care or time off from work).

3. Promotion

In informing people about an organization and what it has to offer, the cost of and program marketer's expertise or familiarity with the promotional methods chosen must be balanced with the likelihood that the target audience uses that medium. For example, an article printed for free in the local weekly newspaper may not be read and a late-night radio public service announcement may not be heard by your intended audience.

4. Place (also referred to as Distribution)

To satisfy customers, products must be available at the right time in a convenient and accessible location. It's really about access. A modern, spacious facility may not be useful if clientele cannot not get to it by public transportation, if there is limited parking or if the area is considered unsafe after dark. Web-based programs may limit access to only audiences with home computers and fast Internet connections.

Problems in Implementing the Marketing Concept

Despite the benefits of a marketing approach, there are problems and limitations, including: 
1. Takes time, effort, money. Requires good information.

2. May result in conflict with tradition.

3. By satisfying one segment of society, an organization sometimes contributes to the dissatisfaction of other segments.

4. There is a limit to an organization's ability to satisfy clients' specific, exact needs.

5. Effective promotion attracts participants to your program but ... marketing also requires you to have a plan for what to do with them once you've got them.

Kotler and Andreasen (2000, p. 266) summarized the challenge of applying marketing to a nonprofit as follows:

Indoctrinating a non-profit organization from top to bottom with the proper marketing philosophy is not an easy task. The experience of those who have successfully achieved this objective suggest such strategies as: recognizing the limited understanding of others about what marketing really is; allowing for other pressures on the organization that may temporarily mandate non-customer oriented approaches; picking visible, short term projects for the first marketing applications; and recognizing that the introduction of a new philosophy is as much a political exercise as a matter of logic and persuasion. Allies must be sought and enemies deflected. Above all, it is essential to secure top management's commitment to the new way of thinking. Without it a true marketing orientation will not be achieved and customer-centered thrusts in one area will inevitably run foul of organization-mindedness elsewhere.

\section{Using a Marketing Approach to Improve and Expand Your Program}

As stated, marketing is not just the "selling" of a product or service. It is a client-centered approach that attempts to match program offerings with the needs and interests of current and potential clients. Promotion, which is part of marketing, is one of the last steps in a marketing approach, not the first or only!

One of the first steps in using a marketing approach is to formulate a marketing strategy. To do this, it is necessary to determine the goals for your program. Here are some questions you may need to ask (Diem, 1989; 1992a):

- Who is your program trying to serve?

- What is happening in your community or society that will affect your program in the future?

- What should be offered?

- What resources are available to accomplish your goals?

Of course, the answers to some of these questions may already have been determined for you. Others you may have some influence in or authority to define or change.

Marketing can be used in many types of programs and organizations. The following uses a youth development program as an example and is especially applicable to any program that is an optional activity for kids, where enrollment depends on a choice youth, and people who 
influence them regarding whether to join or not. In consideration of this, here is a simple, three-step approach to employing marketing principles in your program (Diem, 1989):

1. Determine what the current participants in your program think about the program.

- What do they like about it?

- Why did they enroll and who convinced them to do so?

- What don't they like about it and what suggestions do they have for improvement?

2. Find out what others think about the program.

- What do they think the program offers?

- Why didn't they enroll?

- Who influenced their decision? (Try to talk to those people too.)

- What would interest them to enroll?

Various methods can be used to find needed information. A few are:

- Written questionnaires

- Personal or telephone interviews

- Discussions at participant and staff/volunteer meetings, classes \& workshops

- Opinion questions on applications, enrollment forms

- A comprehensive review of your program every 3-5 years

Finding out what people think is very important. Remember, that people's perceptions of reality, not just the actual facts, influence people's attitudes, decisions, and actions!

3. Determine if there are discrepancies between what people think of your program and what it actually is or you think it should be.

- Devise a plan of action to alleviate or minimize these discrepancies. This is your marketing strategy.

- Your marketing strategy will probably differ from one aspect of your program to another. This means that one approach won't work for every situation.

- Gear your promotion efforts toward the people you're attempting to attract. If you don't target your message to a specific audience, your message may not get through to anyone.

An Advisory Group Can Help:

- If you don't already have one, consider organizing a working advisory group for your program.

- The group might be composed of community leaders, current and former participants, parents, and volunteers, and other staff.

- To get representative views, a mixture of people who know the program well and those who don't may help generate objective opinions and a greater variety of ideas.

- Your advisory group could be formed just to make initial recommendations for changes in your program or to help promote it. Ideally, it would meet on an ongoing basis. 
- Many people in youth development organizations think that advisory groups are merely a formality and a hassle. Consider that industry puts big money into similar groups; they call them "focus groups."

\section{Conclusions \& Recommendations}

- Using the marketing approach to your program can result in improved program quality as well as increased enrollment.

- Keeping your program current in meeting needs and interests of your clientele, the community, and society is essential.

- Promoting an accurate and relevant image is the key in making sure people realize the value of your program.

The importance of this challenge is emphasized by the likelihood that satisfied "customers" will tell a few friends about the "product" but, unfortunately, those who are dissatisfied are likely to tell even more people of their bad experience; an unfortunate but common phenomenon of human nature. It is also further incentive to work hard at maintaining and promoting a valuable, interesting, and relevant program - the "product" in an educational organization or youth development program.

Lastly, realize that "social marketing is founded on trust. It is not driven by profit but, at least ostensibly, a desire to benefit the target audience. It therefore has a very different, and perhaps, morally higher, base than commercial marketing on which to build mutual respect with its customers" (Hastings, 2003, p. 9).

\section{References}

Boyle, P.G., \& Brown, E.J. (1964). Adapting 4-H to urban situations. Journal of Extension [Online], 2(1), 29-36. Available at: http://www.joe.org/joe/1964spring.

Bureau of Labor Statistics, U.S. Department of Labor. (2002). National Longitudinal Survey of Youth 1979 cohort, 1979-2002. Produced and distributed by the Center for Human Resource Research, The Ohio State University. Columbus, OH. Available online: http://www.bls.gov/nls.

Diem, K.G. (1987). The relationship of marketing activities and promotional methods used with county 4-H club membership in New Jersey and Ohio. Ph.D. dissertation. The Ohio State University, Columbus.

Diem, K.G. (1989, October). Using a marketing approach to improve and expand your county 4-H program. National Association of Extension 4-H Agents News and Views, p. 5.

Diem, K.G. (1990). The Image of the 4-H Youth Development Program and Rutgers Cooperative Extension of Somerset County, NJ: A study of public awareness and perceptions. Abstract in 1988-1989 Summary of Research in Extension, Volume 4. Mississippi State University, Starkville. 
Diem, K.G. (1991, July). Overcoming myths of 4-H youth and volunteer resources: Don't wonder, just ask! National Association of Extension 4-H Agents News and Views.

Diem, K.G. (1992a). Putting marketing concepts into practice in 4-H. (Seminar presentation). Proceedings from National Association of Extension 4-H Agents national conference, Kansas City, MO.

Diem, K.G. (1992b). How youth find out about 4-H and why they join. Abstract in 1990-1991 Summary of Research in Extension, Volume 5. Mississippi State University, Starkville.

Diem, K.G. (1992c). The value of 4-H according to parents of 4-H club members in Somerset County, NJ. Abstract in 1990-1991 Summary of Research in Extension, Volume 5. Mississippi State University, Starkville.

Diem, K.G. (1994). What do youth like? A survey of youth interests in Somerset County, NJ. Abstract in 1993-1994 Summary of Research in Extension, Volume 6. Mississippi State University, Starkville.

Diem, K.G. (1997). Measuring impact of educational programs. Rutgers Cooperative Extension fact sheet \#869. New Brunswick, NJ: Rutgers University. Available online:

http://njaes.rutgers.edu/pubs/publication.asp?pid=FS869.

Diem, K.G., \& Rothenburger, L. (2001, August). The County Fair - What has it done for you, lately?, Journal of Extension [On-line], Volume 39(4). Available at:

http://www.joe.org/joe/2001august/iw1.html.

Diem, K.G. (2003, January). Program development in a political world - it's all about impact!, Journal of Extension [On-line], 41(1). Available at:

http://www.joe.org/joe/2003february/a6.shtml.

Diem, K.G. (2007). Determining the degree and training needs of youth development professionals: A national survey of leaders of prominent youth development organizations. Unpublished needs assessment. Clemson University College of Health, Education, \& Human Development. Clemson, SC. (Accepted for publication in Journal of Extension at www.joe.org)

Engel, J.F., \& Blackwell, R.D. (1982). Consumer Behavior (4th ed.). Hinsdale, IL: Dryden Press.

Engel, J.F., Warshaw, M.R., \& Kinnear, T.C. (1983). Promotional strategy: Managing the marketing communications process (5th ed.). Homewood, IL: Richard D. Irwin, Inc.

Fishbein, M., \& Ajzen, I. (1975). Belief, attitude, intention and behavior: An introduction to theory and research. Reading, MA: Addison-Wesley.

George, W.R., Buchanan, W.W., \& Bramblett, L.R. (1976). A marketing management strategy. Journal of Extension, 14(6), 13-19. Available at: http://www.joe.org/joe/1976november/76-6a2.pdf. 
Hastings, G. (2003). Relational paradigms in social marketing. Journal of Macromarketing, 23, 6-15.

Johnston, M. (1982). Can mass media change behavior? Journal of Extension [On-line]. 20(3), 10-14. Available at: http://www.joe.org/joe/1982may/82-3-a2.pdf.

Kotler, P. (1980). Principles of marketing. Englewood Cliffs, NJ: Prentice-Hall, Inc.

Kotler, P., \& Andreason, A.R. (2000). Stategic marketing for non-profit organizations. In M.J. Baker (Ed.), Marketing theory: A student text (p. 266). South Melbourne, Australia: Cengage Learning EMEA.

Lawson, W.M., \& Dail, H.M. (1966). Sources of information for farmers. Journal of Extension [On-line], 4(3), 163-168. Available at: http://www.joe.org/joe/1966fall/1966-3-a4.pdf.

Marsh, S.A., \& Knox, A.B. (1966). Information seeking and adult education. Journal of Extension, 4(4), 213-222. Available online at http://www.joe.org/joe/1966winter/1966-4-a3.pdf.

Meenaghan, T. (1995). The role of advertising in brand image development. Journal of Product \& Brand Management. 4(4), pp. 23-34. MCB UP Ltd.

Pride, W.M., \& Ferrell, O.C. (1985). Marketing: Basic concepts and decisions (4th ed.). Boston: Houghton Mifflin.

Salcedo, R.N. (1974). Blood and gore on the information campaign trail. Journal of Extension [On-line], 12(2), 9-19. Available at: http://www.joe.org/joe/1974summer/1974-2-a1.pdf.

Scherer, C. (1980). Does paid promotion pay? Journal of Extension [On-line]. 18(2), 4-8. Available online: http://www.joe.org/joe/1980march/80-2-a1.pdf.

Warner, P.D., Christenson, J.A., Dillman, D.A., \& Salant, P. (1996). Public perception of Extension. Journal of Extension [On-line], 34(4). Available at: http://www.joe.org/joe/1996august/a1.html.

Whitlock, J.L., \& Hamilton, S.F. (2003, January). The role of youth surveys in community youth development initiatives. Applied Developmental Science, 7 (1), 39 - 51.

Williams, M. (2004). Analysis of minority participation in Texas' East Region 4-H and Youth Development Program in relationship to leadership, marketing, and educational opportunities. Ed.D. dissertation. Texas Tech University, Lubbock.

Wilson, R. (1963). Rural families and the mass media. Journal of Extension [On-line], 1(1), 4146. Available online: http://www.joe.org/joe/1963spring/1963-1-a7.pdf.

(C) Copyright of Journal of Youth Development $~$ Bridging Research and Practice. Content may not be copied or emailed to multiple sites or posted to a listserv without copyright holder's express written permission. Contact Editor at: patricia.dawson@oregonstate.edu for details. However, users may print, download or email articles for individual use.

ISSN 2325-4009 (Print); ISSN 2325-4017 (Online) 